\title{
26. AMORPHOUS IRON OXIDE PRECIPITATES IN SEDIMENTS CORED DURING LEG 5, DEEP SEA DRILLING PROJECT
}

\author{
C. C. von der Borch, Scripps Institution of Oceanography, La Jolla, California \\ and \\ R. W. Rex, University of California, Riverside, California
}

\section{INTRODUCTION}

The sediment column at Sites 37, 38 and 39, Leg 5, of the Deep Sea Drilling Project (locality map, Figure 1) is dominantly a dark brown unconsolidated "mud", composed in part of a non-crystalline iron oxide mineral. X-ray diffraction studies by Rex (this volume) verify its non-diffracting, amorphous nature. This ferruginous material appears identical to metal oxide precipitates described by Bostrom and Peterson (1966), Bostrom et al. (1969), and Bostrom and Peterson (1969) which were associated with areas of high heat flow near the crest of the mid-ocean ridge system, particularly the East Pacific Rise. It is also similar, at least in textural detail, to the so-called Amorphous Goethite Facies of the Red Sea metalliferous sediments, described by Bischoff (1969). In all documented cases, these unusual sediments appear to be associated with the mid-ocean ridge system or with related rift structures. If the hypothesis of sea-floor spreading is correct, then such a metal-rich facies would be expected to occur as a basal deposit immediately overlying basaltic "oceanic basement" in many areas of the ocean basins. Site 9, Leg 2, of the Deep Sea Drilling Project encountered hematite-rich sediments just above igneous rock, and this occurrence was interpreted by Peterson et al., 1970 , as being due to precipitation near hydrothermal sources at a prior oceanic ridge crest. The fact that basal iron-rich sediments were also encountered at Sites 37, 38 and 39, Leg 5, of the Deep Sea Drilling Project in areas remote from a present-day ridge system calls for a detailed description of the mineralogical and sedimentological associations occurring at these sites.

\section{STRATIGRAPHIC RELATIONSHIPS}

Generalized stratigraphic columns of Sites 37,38 and 39 are shown in Figure 1. Basalt was reached at Sites 37 and 39 with no obvious indications in the recovered sediment of baking at the contact. No igneous rock was sampled at Site 38 , although a hard layer, probably basalt, terminated the drilling. In all three holes, three distinct facies were recognized which are described in detail below. These facies are: Basal amorphous ironmanganese oxide facies; mixed amorphous iron-manganese oxide-detrital facies; and, detrital facies. The criteria by which these facies are recognized differ somewhat from those used in the earlier shipboard facies designations of McManus et al. (this volume).

\section{Basal Amorphous Iron-Manganese Oxide Facies}

Immediately overlying basalt at Sites 37 and 39, a section of 5 to 6 meters of dusky yellowish-brown amorphous goethite "mud" occurs. Small quantities of Lower Eocene calcareous nannoplankton occur near the base of the hole at Site 39. At Site 38, the basal 9-meter section of sediment is a mixture comprising sub-equal amounts of amorphous iron-manganese oxides and calcified Lower Eocene calcareous nannoplankton, overlain by 6 meters of the 100 per cent amorphous iron-manganese oxide sediment. In all three sites this sediment association is designated the "basal amorphous iron-manganese oxide facies". Apart from the local admixture of nannoplankton, an ash bed at Site 37 and scattered aggregates of phillipsite, this facies is essentially a pure iron-manganese oxide sediment, free from crystalline detritus. Bulk X-ray diffraction studies (Rex, this volume) and microscopic smear slide observations point to a relatively sharp boundary between this facies and the overlying unit described below.

\section{Mixed Amorphous Iron-Manganese Oxide-Detritial Facies}

Overlying the basal facies at all three sites is a dusky yellowish-brown sediment composed of a mixture of amorphous iron-manganese oxides and crystalline detrital components. This is termed the "mixed amorphous iron-manganese oxide-detrital facies". Microscopic examination shows that the proportion of amorphous iron-manganese oxides decreases in an up-hole direction along with a progressively increasing detrital admixture. Crystalline components, herein broadly characterized as "detrital", include silt-sized quartz and plagioclase, accompanied by kaolinite, mica and chlorite. These minerals may be largely of eolian origin, or they may represent nepheloid layer deposition. Other minerals detected by X-ray diffraction (Rex, this volume) are montmorillonite, phillipsite and localized barite, of authigenic or hydrothermal origin. Scattered manganese nodules occur within this facies at Site 37 , and an ash bed is present at Site 38 . 


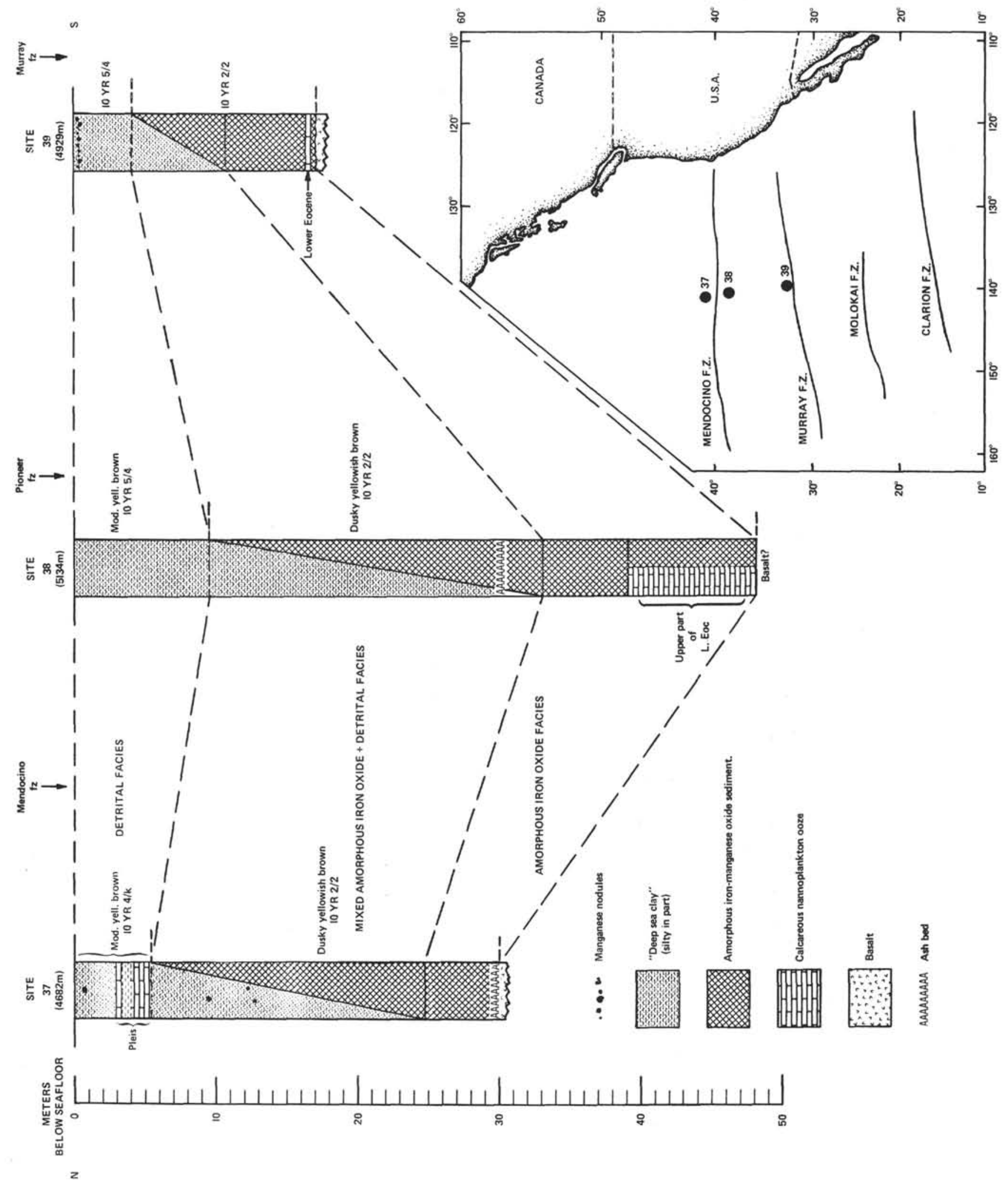

Figure 1. Locality chart and stratigraphic columns of Sites 37, 38 and 39 of the Deep Sea Drilling Project. Color code is from the U.S. G.S. rock color chart. 
The upper level of this facies is not as well-defined as its lower boundary. However, the dashed line shown in the stratigraphic columns in Figure 1 approximates the zone above which essentially no amorphous ironmanganese oxides are observed in smear slides. Age relationships of this facies are uncertain, due to lack of fossil remains in all three sites.

\section{Detrital Facies}

The gradational upper boundary of the "mixed amorphous iron-manganese oxide-detrital facies" coincides with a color change from dusky yellowish-brown below to moderate yellowish-brown above. The lighter color persists to the sediment surface. The upper unit is termed the "detrital facies" and is largely composed of silt-sized quartz and plagioclase, along with kaolinite, mica, chlorite, barite (in Site 37 ) and montmorillonite (in Site 38). Generally speaking, this sediment type is equivalent to that described in "deep sea brown clay" by the majority of marine geologists. Several layers containing Pleistocene calcareous nannoplankton occur in this facies at Site 37. Manganese nodules and micronodules occur sporadically within the sediment at Sites 37 and 39.

\section{MINERALOGY OF THE AMORPHOUS IRON-MANGANESE OXIDE SEDIMENT}

Smear slide observations show the iron oxide sediment collected on Leg 5 to be composed of a mixture of colloidal material and microscopic sub-spherical grains. When dispersed in distilled water, a reddish-brown colloidal suspension persists for many days before settling, a property similar to that observed in equivalent sediments from the crest of the East Pacific Rise (Bostrom and Peterson, 1966). The actual iron oxide spherules are translucent and amorphous and vary in color from light to dark yellowish-brown in transmitted light. Darker hues may be indicative of admixtures of manganese oxides, in a manner comparable to East Pacific Rise analogues (Bostrom and Peterson, 1969).

The ferruginous spherules range in size from 0.5 microns to 25 microns, being dominantly about 5 microns in section. Larger particles appear to be aggregates that survived treatment with an ultrasonic probe. In general, the size range is equivalent to that observed by Bischoff (1969) in sediment of the Red Sea Amorphous Goethite Facies.
Amorphous iron-manganese oxides described by Bostrom and Peterson (1969) from the East Pacific Rise surface sediments show low aluminum and titanium values and significant enrichments of iron, manganese, boron, arsenic, cadmium, vanadium and chromium, compared with average pelagic sediments. Neutron activation analyses for major elements in selected Leg 5 samples (Kuykendall, this volume) show comparable enrichments in iron, up to 27.85 per cent of the sediment, and relatively low aluminum values of 0.86 to 2.82 per cent.

\section{DISCUSSIONS}

The occurrence at Sites 37,38 and 39 of a basal amorphous iron-manganese oxide sediment suggests that this material is a primary precipitate. The necessary localized enrichment of iron, along with possible manganese and trace metals, is best explained by hypothesizing the presence of submarine hydrothermal exhalations synchronous with deposition. According to the present state of our knowledge, the observed stratigraphic and mineralogic relationships are best understood by invoking the sea-floor spreading hypothesis. With such a model, the volcanic "basement" at Sites 37,38 and 39 would have originated in the vicinity of a ridge crest. In this particular case, the ridge may have been subsequently over-ridden by the southwestern portion of North America. Hydrothermal exhalations along the crestal zone of the ridge could cause precipitation of the metal oxides, leading to the trapping of a relatively pure deposit in possible topographic basement lows. Precipitation at the crestal zone may have been rapid enough that virtually no admixtures of eolian or other extraneous material occurred, with the exception of penecontemporaneous influxes of calcareous pelagic sediments at Site 38 and to a minor extent at Site 39. As sea-floor spreading subsequently moved the area away from the hydrothermal zone of the ridge crest, precipitation of metal oxides in any one area would have become progressively less, and sedimentation would have been increasingly dominated by detrital processes. This model, suggested by Bostrom and Peterson (1966) from observations of surface sediments across the East Pacific Rise (Figure 2), adequately explains the vertical sequence cored at Deep Sea Drilling Sites 37,38 and 39. 


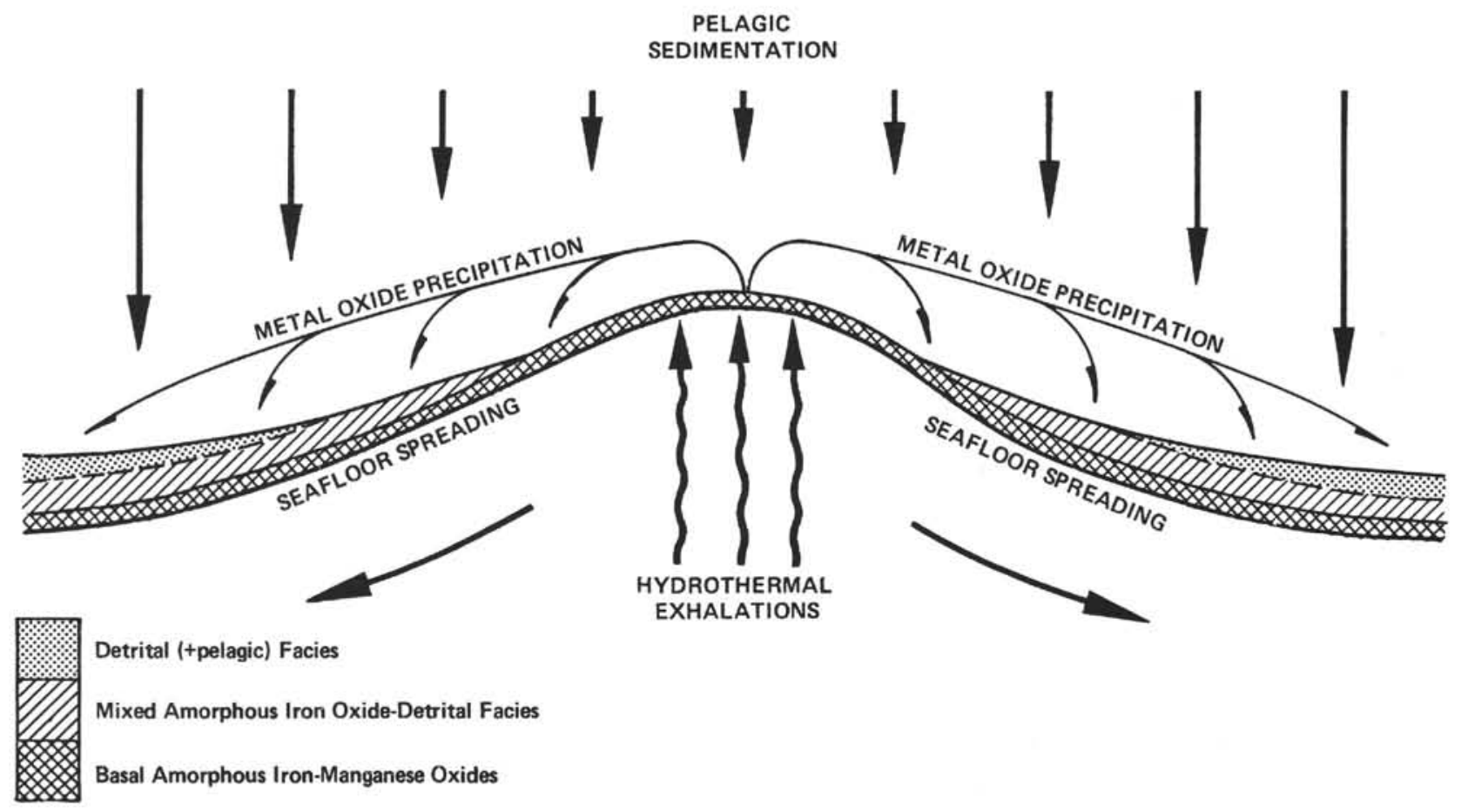

Figure 2. Schematic representation of sedimentation processes on the East Pacific Rise. (Adapted and modified from Bostrom and Peterson, 1969.)

\section{REFERENCES}

Bischoff, J. L., 1969. Red Sea geothermal brine deposits: Their mineralogy, chemistry and genesis. In Hot Brines and Recent Heavy Metal Deposits in the Red Sea. Degens and Ross (Eds.). New York (Springer-Verlag) 368.

Bostrom, K. and Peterson, M. N. A., 1966. Precipitates from hydrothermal exhalations on the East Pacific Rise. Econ. Geol. 61, 1258.

, 1969. The origin of aluminum-poor ferromanganoan sediments in areas of high heat flow on the East Pacific Rise. Marine Geol. 7, 427.

Bostrom, K., Peterson, M. N. A., Joensuu, O. and Fisher, D. E., 1969. Aluminum-poor ferromanganoan sediments on active oceanic ridges. J. Geophys. Res. 74, 3261 .
Kuykendall, W. E., Hoffman, B. W. and Wainerdi, R. E., 1970. 14-MeV neutron activation analysis of selected Leg 5 core samples. In McManus, D. A. et al., 1970. Initial Reports of the Deep Sea Drilling Project, Volume V. Washington (U.S. Government Printing Office).

Peterson, M. N. A., Edgar, N. T., von der Borch, C. C. and Rex, R. W., 1970. Cruise leg summary and discussion (Leg 2). In Peterson, M. N. A. et al., 1970. Initial Reports of the Deep Sea Drilling Project, Volume II. Washington (U.S. Government Printing Office) 413.

Rex, R. W., 1970. Bulk X-ray diffraction results, Leg 5. In McManus, D. A. et al., 1970. Initial Reports of the Deep Sea Drilling Project, Volume V. Washington (U.S. Government Printing Office). 